症例

横行結腸浸潤を伴った腸間膜デスモイド腫瘍の 1 例

山陰労災病院外科

坂本 照 尚* 若 月 倰 郎 野坂 仁 愛
竹 林 正 孝

デスモイド腫咟は組織学的には良性腫瘍とされているが，局所再発や浸潤性発育のた め臨床的には良・悪性境界腫煌と定義されている. 今回，われわれは腸間膜デスモイド 腫湯の 1 例を経験したので報告する.症例は61歳, 男性で腹部腫瘤を主訴に近医を受診 し, 腹部超音波にて腹腔内腫瘍を指摘され，当院へ紹介された，小腸透視検査，注腸透 視, 腹部超音波検查, CT で後腹膜腫韵もしくは腸間膜腫崵が疑われ, 開腹手術が施行さ れた．腫場は腸間膜に位置し，横行結腸に漫潤していたため，腫瘍摘出術および横行結 腸部分切除術が行われた。腫瘍は $5.5 \times 5 \times 4 \mathrm{~cm}$ の白色充実性腫場であり, 病理組織検 查にて腸間膜デスモイド腫瘍と診断された，本症例は家族性大腸腺腫症の合併や手術既 往のない自然発症例で稀な症例である. 浸潤性であり今後も経過観察の必要がある.

㮂引用語：腸間膜デスモイド腫湟，デスモイド腫瘍

粕 言

デスモイド腫瘍は稀な線維性腫場とされ，発生部位 により腹壁・腹壁外・腹腔内に大別される。また，組 織学的に核分裂像にそしく良性腫瘍とされているが， 周囲浸潤性発育・局所再発ゆ元臨床的には良・悪性境 界腫湟に位置づけられていう.今回, われわれは横行 結腸浸潤を呈した腸間膜デスモイド腫場の 1 例を経験 したので, 若干の文献的考察を加えて報告する.

症 例

症例：61歳, 男性.

主訴 : 腹部腫瘤.

既往歴：特記すべきことなし。

家族歴：特記すべきことなし.

現病歴: 平成 13 年 5 月下旬, 腹部腫㿔を自覚し近医 受診した. 同年 6 月 4 日, 精查加療のため当院内科へ 紹介された。精查の結果, 後腹膜腫葲あるいは腸間膜 腫緜と診断され同年 7 月 3 日，手術目的に当科入院と なった.

入院時現症：實血, 黄疸なく, 体表リンパ節は触知

2005 年 2 月 3 日受付 2005 年 4 月 20 日採用

*現：鳥取大学病態制御外科

〈所属施設住所〉

于683-8605 米子市皆生新田 $1-8-1$
しなかった． 右下腹部に可動性を有する鶏卵大の弾性 硬腫瘤を触知した。

血液検查： $\mathrm{CPK}$ が $167 \mathrm{mg} / \mathrm{dl}$ と軽度高値を示したほ か，異常を認めなかった。

腹部超音波検查：右下腹部に周囲と境界明暸で内部 ほほ均一な $47 \times 45 \mathrm{~mm}$ の低エコーの腫瘤性病変として 描出された（図 1 ).

経口小腸透視検査：腫瘍部位を中心に小腸の圧排像 を認めた（図 2 ）。

注腸透視検査：横行結腸肝彎曲側が尾側への牽引, および横行結腸粘膜の引きつれも認めた（図 3 ).

腹部 CT 検查：単純 CT において下腹部やや右側に $5 \times 4 \mathrm{~cm}$, 内部に均一な低吸収域を示す充実性腫瘤を 認めた。造影 CT ては一部造影効果のそしい部位を認 めるものの, 淡く均一な造影効果を呈していた（図 4$).$

以上より後腹膜腫瘍もしくは腸間膜腫瘍の診断のも と, 同年 7 月 4 日手術を施行した。

手術所見：腫場は小腸間膜に小児手拳大, 球形状腫 瘤として存在し，一部横行結腸を巻き込んでいた（図 $5)$. 小腸間膜を温存する形で処理を行ったが, 横行結 腸との剝離が困難であったため, 横行結腸を部分切除 し腫場と共に摘出した.

切除標本：腫瘤は $5.5 \times 5 \times 4 \mathrm{~cm}$, 弾性硬, 被膜を有 さず内部は白色調を呈し充実性であった。 


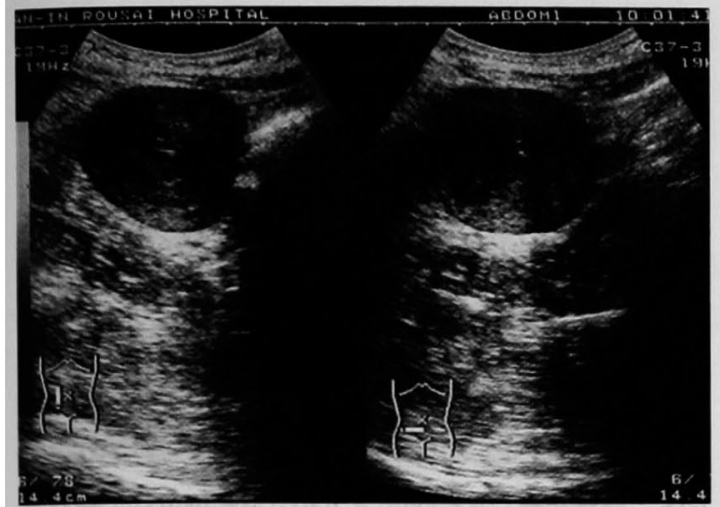

图 1 腹部超音波：右下腹部に周囲と境界明膫で部ほ ほ均一な47-45mmの low echoic mass を認めた。他葴 器との連続性はなかった。

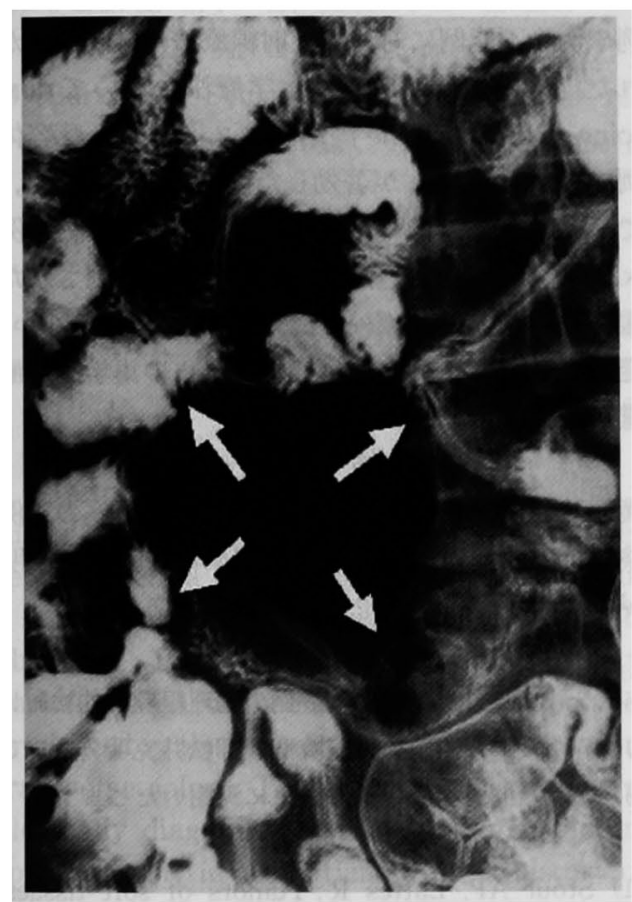

図 2 経口小腸透視：腫暍部位を中心に小腸の圧 排像を認めた（矢印）。

病理組織：HE 染色にて細胞異型のない線維芽細胞 と膠原線維で構成されていた(図 6 )。浸潤性增殖を示 し, 横行結腸の筋層まで浸潤を認め, 腸間膜由来のデ スモイド腫場と診断された。

術後経過：術後11日軽快退院した. 現在, 術後 3 年 6 カ月経過して再発を認めていない.

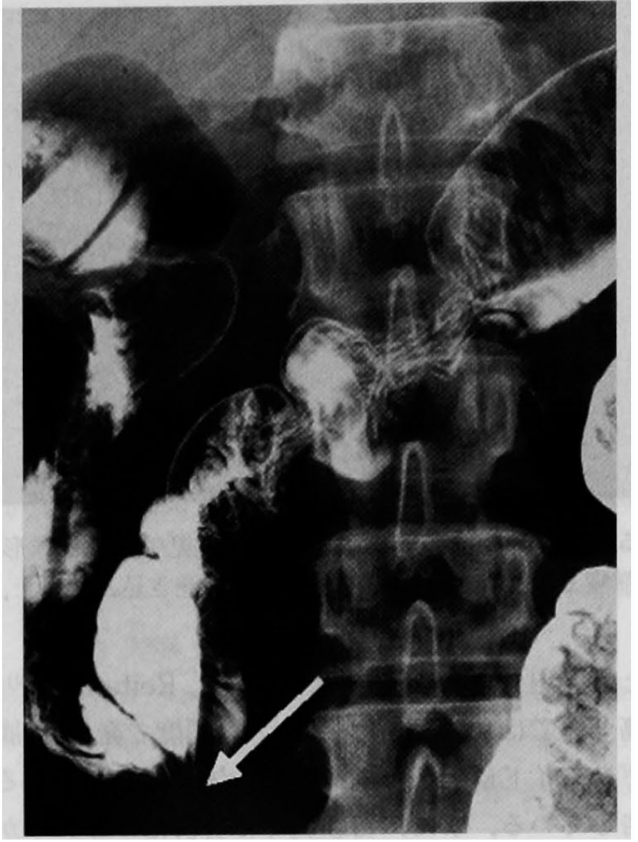

図 3 注腸透視：横行結腸肝雾曲側が尾側に率 引,かつ,横行結腸粘膜の引きつれも認めた(矢 印).

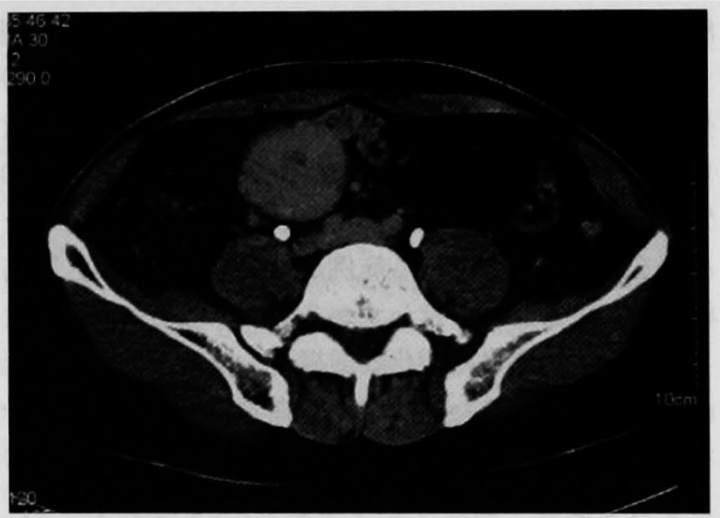

図 4 造影 CT：一部造影効果の乏しい部位を認めるもの の, 淡く均一な造影効果を呈していた。

\section{考察}

Stout ら"の定義によりデスモイド腫瘍は組織学的 に分化した線維芽細胞の増殖および多量の膠原線維が 存在し，浸潤性発育を呈するが核分裂像の悪性所見は なく，遠隔転移はしないものの局所再発を認めるとさ れている。発生部位により腹壁外デスモイド，腹壁デ スモイド，腹肪内デスモイドの 3 つに大別され，さら に腹腔内デスモイドは自験例が属する腸間膜デスモイ 


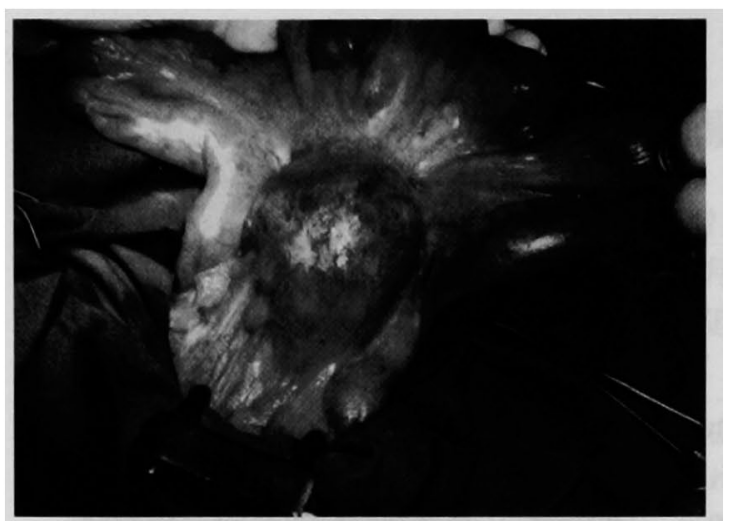

図 5 術中所見：腫瘍は小腸間膜に小児手拳大,球形状 腫瘤として存在し，一部横行結腸を巻き込んでいた。

ドと骨盤内デスモイドに分けられる. Reitamoら ${ }^{2}$ は， 腫場全体では 100 万人当たり 3 人の頻度で発生し,腸間 膜デスモイドはデスモイド腫瘍全体の約 8 \%であると 報告している。 また，自験例では合併はみられなかっ たが, しばしば Gardner 症候群に合併することが知ら れている.成因としては手術などの機械的剌激の他に, 妊娠，エストロゲン受容体の関与が指摘されている が3，今なお不明な点が多い. 本邦では自験例を含め,

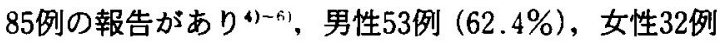
(37.4\%) と男性に多く, 部位別では小腸間膜からの 発生が最も多く,85例中57例（67.1\%）であった，次 いで結腸間膜であった，開腹手術の既往は28例 (32.9 \%)にみられた．手術術式においては浸潤性発育のた め腸を合併切除している症例がほとんどであり，腫瘍 核出術が行われたのはわずか 3 例のみであった。

一般的に本疾患は消化管透視上，腫瘍による消化管 の圧排や偏移，また，超音波検査では境界明睹で均一 な低エコー性腫瘤として描出され，膠原線維の増生に よる音響陰影が認められると言われている7. CT, MRI，血管造影において特異的所見に乏しいため術前 診断は極めて難しく，自験例においても間葉系腫場を 第一に考えたが，本疾患の診断には至らなかった。ま た，針生検が術前診断に有効との報告もあるが8)，本疾 患の浸潤性発育，局所再発の性質上好ましくないと考 える.

腸間膜デスモイドの治療は完全外科的切除が原則で ある。しかしながら, 発見された時点で周囲蔵器に浸 潤していることが多く他臓器合併切除を余儀なくされ る場合が殆どである．自験例においても横行結腸への 浸潤のため横行結腸部分切除術を併せて行った。術後

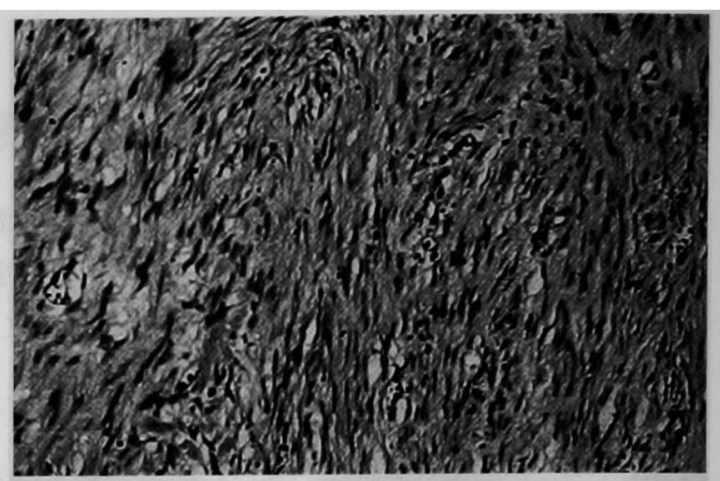

图 6 病理組織 (HE 染色, $\times 100) ： \mathrm{HE}$ 染色にて細胞異 型のない線維芽細胞と膠原線維で構成されていた。

の再発例は少なくなく, Burke ら は完全切除例の $22.2 \%$ に再発を認めたと報告している。このような再 発例や切除不能例に対して放射線療法や菜物療法が行 われた症例が散見される。化学療法において doxor. ubicine と dacarbazine 併用やエストロゲン受容体陽 性例で tamoxifen が著効した症例や10111, また, 最 近では c-kit 陽性例にメシル酸イマチニブ使用例や Cox2 阻害剂でデスモイド細胞の増殖が抑制されたと の報告もある ${ }^{12) 13)}$. 治療として確立されてはいないが， 再発例や切除不能例に対してはこれらの集学的治療も 考慮されるべきである.

\section{結 語}

横行結腸に浸潤した腸間膜デスモイド腫煬の1例を 経験したので報告した，発生原因や治療も含め不明な 点が多く, 症例の蓄積や研究が必要でる。

\section{謝辞}

本稿を終えるにあたり，本症例の病理組織学的検討にご 尽力をいただいた山陰労災病院病理部松井克明先生, ご指 埒賜りました同外科大谷㝘二先生に溧謝いたします。

\section{文献}

1) Stout AP, Lattes R: Tumors of soft tissues. Atlas of Tumors Pathology, 2nd series, Fascicle 1, Armed Forces Institute of Pathology, Washington DC, 1967, p451-454

2) Reitamo JJ, Hayry P, Nykyri E, et al: The desmoid tumor. Am J Clin Pathol 77 : 665-673, 1982

3) Hayry P, Reitamo JJ, Totterman S, et al : Analysis of factors Possibly Contributing to the Etiology and Growth Behavior. Am J Clin Pathol $77: 674-680,1982$ 
4）柴田康行，桑原義之，筆田害幸他：腸間膜デスモ イド腫瘦の 2 例。日臨外会誌 $63: 2558-2563$, 2002

5) 岡田健一, 清水壮一, 黒田浩章他: 腸間膜デスモ イド尰疸の 1 例. 日臨外会誌 $64: 1489-149^{2}$, 2003

6）村上 真, 前田浩幸，広野靖夫 他：横行結腸間膜 に発生した intra-abdminal desmoid $の 1$ 例. 日 消外会誌 $36: 294-298,2003$

7) Sakurai N, Takeuchi K, Nagashima N, et al : The characteristic US images of the mesenteric desmoid tumor, acoustic shadows appeared in the mass lesion. J Med Ultrasonics 28: J592, 2001

8）伊藤広之, 清水 哲, 更級麻子他：腸間膜デスモ イド腫瘍の 1 例. 日消外会誌 $30 ： 430,1997$

9) Burke AP, Sobin LH, Shekitka KM, et al : Mesenteric fibromatosis. A pathologic analy. sis of 130 tumors with comparison of clinical subgroups. Arch Pathol Lab Med 114 : 832835,1990

10) Patel SR, Evans HL, Benjamin RS : Combination chemotherapy in adult desmoid tumors. Cancer $72: 3244-3247,1993$

11) Lim CL, Walker MJ, Mehta RR, et al : Estrogen and antiestrogen binding sites in desmoid tumors. Eur J Cancer Clin Oncol $22: 583$ $-587,1986$

12）藤江裕二郎, 山本浩文, 池田正孝他：切除後再発 を繰り返す腹腔内デスモイド腫瘍に対して×シル 酸イマチニプを使用した 1 例. 手術 $58 ： 1789$ 一 1792, 2004

13) Poon R, Smits R, Li C, et al : Cyclooxygenasetwo modulates proliferation in aggressive $\mathrm{fi}$ bromatosis (desmoid tumor). Oncogene $20: 451$ $-460,2001$

\title{
A CASE OF MESENTERIC DESMOID TUMOR INVADING THE TRANSVERSE COLON
}

\author{
Teruhisa SAKAMOTO, Toshiro WAKATSUKI, Kimiyasu NOZAKA, \\ Masataka TAKEBAYASHI, Akira KAMASAKO and Osamu TANIDA \\ Department of Surgery, Sanin Rosai Hospital
}

Desmoid tumor is histologically a benign tumor, however, it is clinically designated as a borderline tumor between benignancy and malignancy because it locally recurs and shows an invasive growth. We report herein a case of mesenteric desmoid tumor invading the transverse colon.

A 61-year-old man was admitted to the hospital because of an abdominal mass in the right lower abdomen. The lesion was suggested to be a tumor originated in the retroperitoneum or mesentery by barium enema, ultrasonography, and computed tomography. A lapalotomy disclosed that the tumor was originated in the mesentery and invaded the transverse colon. We resected the tumor with a part of the transverse colon. The resected mass which was a $5.5 \times 5 \times 4 \mathrm{~cm}$ white solid tumor was histopathologically diagnosed as intra-abdominal desmoid tumor. This desmoid tumor is thought to develop spontaneously in the patient without history of undergoing abdominal surgery or familial adenomatous polyposis, which is very rare. Further close observation is required because the tumor invaded the transverse colon. 